\title{
Analisis Kalām Khabari dalam Kitab Lubāb al-Hadīs Karya Jalaluddin al-Suyuthi
}

\author{
Ahmad Fajar ${ }^{1}$ \\ Taufik Luthfi ${ }^{2}$
}

DOI: https://doi.org/10.52593/klm.03.1.05

Naskah diterima: 2021-12-31, direvisi: 2022-01-18, disetujui: 2022-01-18

\begin{abstract}
Abstrak
Penelitian ini fokus pada salah satu karya dari Jalaluddin bin Kamaluddin al-Suyuthi yaitu Lubāb al-Hadīs yang terdiri dari empat puluh bab, pada setiap bab-nya memuat sepuluh Hadīs dengan keseluruhannya berjumlah empat ratus Hadìs. Kitab ini berisi tentang keutamaan-keutamaan, larangan-larangan dan pencegaan dari Hadīs-Hadīs Nabi saw., Hadīs Qudsi dan Asar sahabat. Tujuan dari penelitian ini adalah untuk mengetahui Kalām Khabari dan macam-macamnya yang terdapat dalam kitab Lubāb al-Hadīs. Metode penelitian yang digunakan dalam penelitian ini adalah metode studi literatur (literature study), yang merupakan serangkaian kegiatan yang berkenaan dengan metode pengumpulan data pustaka, membaca mencatat, kemudian mengolah bahan penelitian. Dari empat ratus Hadīs dalam empat puluh bab, diambil empat puluh Hadìs sebagai sampel pada penelitian ini. Sehingga hasil dari analisis terhadap kitab Lubāb al-Hadīs ditemukan Kalām Khabar Ibtidā'I sebanyak 88\% dan Kalām Khabar Talabi sebanyak 12\%, sementara tidak ditemukan Kalām Khabar Inkāri.
\end{abstract}

Kata Kunci : Hadīs, Kalām Khabari, Lubāb al-Hadīs

\begin{abstract}
This study focuses on one of the works of Jalaluddin bin Kamaluddin al-Suyuthi, namely Lubāb al-Hadith which consists of forty chapters, each chapter contains ten Hadīs with a total of four hundred Hadìs. This book contains about the virtues, prohibitions and prevention of the Hadīs of the Prophet, the hadith Qudsi and Asar. The purpose of this study was to find out Kalam Khabari and its various types contained in the book of Lubāb al-Hadith. The research method used in this research is the literature study method, which is a series of activities related to the methods of collecting library data, reading and taking notes, then processing research materials. of the four hundred Hadīs in forty chapters, Forty Hadīs have been taken as samples in this study. So the results of the analysis of the Lubāb al-Hadis book found that 88\% of Kalām Khabar Ibtidā'I and 12\% of Kalām Khabar Talabi were found, while Kalām Khabar Inkāri was not found.
\end{abstract}

Keywords: Hadith, Kalām Khabari, Lubāb al-Hadith

\footnotetext{
${ }^{1}$ STAI DR. KH. EZ Muttaqien Purwakarta, ahmadfajar@staimuttaqien.ac.id.

2 STAI DR. KH. EZ Muttaqien Purwakarta, taufikluthfi@staimuttaqien.ac.id.
} 


\section{A. Pendahuluan}

Bahasa digunakan manusia sebagai alat komunikasi untuk saling menyampaikan pesan, keinginan, harapan, perasaan, perintah, larangan dan maksud pikiran lainnya. Bahasa juga menjadi bentuk representatif manusia dalam berpikir. Dengan bahasa manusia dapat berkomunikasi sehingga manusia mempunyai peran sebagai makhluk sosial. Bahasa juga bagian dari kebudayaan masyarakat yang erat kaitannya dengan berpikir. Bahasa adalah alat intelektual paling fleksibel dan memiliki kekuatan yang dikembangkan oleh manusia. Melalui bahasa juga suatu budaya/peradaban dapat dipahami cara berpikir masyarakatnya.

Dengan bahasa arab misalnya, umat islam menulis peradabannya dengan bersumber dari al-Qur'an dan Hadīs yang bahasanya memiliki keindahan yang tinggi. Bahkan dengan keindahan bahasanya, al-Qur'an telah membuktikan diri sebagai mukjizat yang tidak dapat diragukan (Fajar 2020, 37). Bahkan menjadi suatu nilai ibadah bagi siapapun yang membacanya (Luthfi and Rijal Munir 2021, 176).

Pun demikian dengan Hadīs yang menempati posisi kedua setelah al-Qur'an dalam otoritasnya sebagai validitas ajaran agama. Namun tidak seperti al-Qur'an, Hadīs perlu dijaga keontentikannya dengan berbagai macam cara diantaranya metode konfirmasi (Al-Dzahabi 1998). Metode konfirmasi ini telah dilakukan sejak masa sahabat, ini bukan berarti sahabat ragu atau ingkar terhadap Hadīs Nabi saw., konfirmasi ini bertujuan agar meyakinkan mereka bahwa Hadīs yang mereka terima benar-benar berasal dari Nabi saw.

Bahkan masa berikutnya, yakni masa sahabat dan tabi'in terjadi banyak pemalsuan Hadīs oleh beberapa golongan untuk tujuan tertentu dan berbagai kepentingan lainnya. Sebenarnya pemalsuan Hadīs sudah terjadi semasa Nabi saw. masih hidup, dengan mengacu pada salah satu Hadīs Nabi saw. tentang larangan melakukan kebohongan atas nama Nabi saw (Amin 1969, 210).

Pada masa berikutnya akhir abad ke-1 hijriah, ulama Hadīs berupaya menghimpun Hadīs Nabi saw. dengan melakukan lawatan ke berbagai daerah untuk menemui para periwayat Hadīs yang tersebar. Bukan hanya itu, mereka juga 
melakukan penelitian identitas periwayat dan melakukan seleksi Hadīs yang mereka himpun.

Perkembangan Hadīs melewati masa panjang dari abad ke abad, sampai sekitar abad ke-5 Hijriah para ulama Hadīs melakukan usaha klasifikasi Hadīs dengan metode menghimpun Hadīs̀-Hadīs sejenis dalam kandungannya atau sejenis dari sifat-sifat isinya dalam satu kitab Hadīs. Tahap selanjutnya adalah mereka melakukan berbagai macam usaha, diantaranya; men-tashih (seleksi dan penyaringan hadts), men-syarah (menguraikan Hadīs̀), meng-ikhtisar (meringkas), dan usaha lainnya (Al-Munziri 1996, 8). Dengan usaha tersebut melahirkanlah berbagai kitab-kitab Hadīs yang sampai pada masa sekarang, yang diantaranya adalah kitab Lubāb al-Hadīs.

Kitab Lubāb al-Hadīs adalah karya dari Jalaluddin al-Suyuthi seorang ulama besar yang banyak menguasai bidang keilmuan diantaranya bidang ilmu Hadīs. Kitab ini terdiri dari 400 Hadīs yang terangkum dalam 40 bab, pada setiap bab-nya memuat 10 Hadīs. Kitab ini berisi tentang keutamaan-keutamaan, motivasi dalam beribadah, yaitu motivasi dalam anjuran berbuat baik dan larangan-larangan atau pencegahan dari berbuat buruk. Dalam kitab ini Jalaluddin al-Suyuthi menuliskan Hadī̇s-Hadīs Nabi saw. tanpa mencantumkan sanadnya sebagaimana seharusnya. Namun hal tersebut ditempuh agar lebih memudahkan pembaca langsung memahami isi Hadīsnya tanpa harus membaca sanadnya terlebih dulu.

Kitab Lubāb al-Hadīs merupakan salah satu kitab yang cukup populer di Indonesia karena banyak dipelajari oleh para penuntut ilmu agama utamanya oleh santri Pondok Pesantren. Namun untuk memahami Hadīs pada kitab ini diperlukan berbagai bidang ilmu bahasa arab seperti, sintaksis (nahwu), morfologi (Sarf) dan stilistika (balaghah).

Ditemukan oleh peneliti artikel yang mengkaji Kitab Lubāb al-Hadīs, yaitu artikel yang ditulis oleh Nuril Azizah (Azizah 2014) yang diterbitkan oleh Jurnal Dialogia, Vol. 12 No. 1 Juni 2014. Penelitian ini fokus pada Hadīs-Hadīs tentang keutamaan nikah.

Sedangkan pada penelitian ini bertujuan menganalisis Hadīs pada kitab Lubāb al-Hadīs dengan pendekatan balaghah. Balaghah adalah cara mengungkapkan makna yang estetik dengan menggunakan ungkapan yang benar, 
memiliki pengaruh terhadap jiwa dan ungkapannya menyesuaikan dengan lawan bicaranya (Al-Jarim and Amin 1999, 217). Dalam balaghah terdapat tiga kajian penting yaitu; al-ma'ani, al-bayani, al-badi', dalam pembagian cabang ilmu balaghah tersebut pada penelitian ini fokus kajiannya pada al-ma'ani. Kemudian dalam ilmu al-ma'ani terdapat dua topik bahasan yaitu; khabar dan insya. Atas latarbelakang tersebut penelitian ini fokus pada analisis Kalām Khabari dalam kitab Lubāb al-Haddits karya Jalaluddin al-Suyuthi.

\section{B. Teori / Konsep}

\section{Biografi Singkat Jalaluddin al-Suyuthi}

Jalaluddin al-Suyuthi nama lengkapnya adalah Abdurrahman bin Kamaluddin Abu Bakr bin Muhammad bin Sabiquddin, Jalaluddin al-Misri asSuyuthi. Suyuthi sendiri adalah nama yang diambil dari nama daerah kelahirannya di Suyuth, sebuah daerah di Mesir (Jalaluddin al-Suyuthi 2008, 6-7). Sejarah mencatat beliau hidup ketika masa dinasti Mamluk sekitar abad ke-15 M, beliau adalah keturunan Persia, sebelum ke Mesir keluarganya menetap di Baghdad sebagai keluarga terhormat yang mengisi jabatan penting di Pemerintahan.

Pada bulan Rajab/Oktober 849 H/1445 M beliau terlahir di daerah Suyuth (sekitar Kairo). Ia tumbuh menjadi seorang piatu setelah ibunya menginggal sesaat setelah Ia lahir. Saat menginjak usia lima tahun ayahnya meninggal, sehingga Ia tumbuh menjadi anak yatim-piatu. Pada usia delapan tahun Ia telah menghapal alQur'an, ia tumbuh sampai usia sebelas tahun di bawah asuhan Muhammad bin Abd al-Wahid. Al-Dzahabi menceritakan bahwa Jalaluddin al-Suyuthi merupakan seoarang yang alim pada masanya dalam setiap bidang ilmu, baik berkaitan dengan al-Qur'an, Hadīs, dan banyak lagi. Menurutnya, Jalaluddin al-Suyuthi hafal 200.000 Hadīs (Depag RI 1988, 501).

Dalam hal pendidikan, Jalaluddin al-Suyuthi belajar kepada beberapa ulama besar pada masanya. Akibat dari ketekunan dan kecerdasannya Ia diperhitungkan sebagai ulama besar dari berbagai bidang keilmuan. Diantara ulama-ulama besar yang menjadi gurunya adalah; Sirajuddin al-Qalyubi dan syaikh al-Islam al-Bulqaini dari keduanya Ia mempelajari bidang ilmu fiqh, kemudian ilmu fara'id dari Taqiyuddin al-Samni dan Syihabuddin, dan ilmu Hadīs dan Bahasa Arab dari Imam Taqiyuddin al-Hanafi, dalam bidang ilmu Tafsir beliau berguru 
kepada Imam Jalaluddin al-Mahalli. Bahkan yang berkaitan dengan bidang ilmu kedokteran menarik perhatiannya dengan berguru kepada Muhammad bin alDawani (Al-Hanbali 1979, 52). Sepanjang hidupnya ia habiskan dengan terusmenerus mengkaji ilmu-ilmu, sampai-sampai berpindah-pindah dari satu negara ke negara lain. Diantara negara-negara yang pernah dikunjunginya adalah Syam, Yaman, India, Maroko dan negara-negara lainnya.

Melalui karya-karyanya, Jalaluddin al-Suyuthi mendapat pengakuan dari ulama-ulalma besar. Ia adalah seorang yang piawai dalam hal menulis, bahkan seorang muridnya yang bernama al-Dawidi sebagaimana dikutip oleh Husain alDzahabi (Al-Dzahabi 2003) dalam kitabnya menjelaskan bahwa dalam satu hari Imam al-Suyuthi sanggup menuliskan hasil karyanya sebanyak 48 lembar. Lebih lanjut al-Dawidi mengatakan bahwa jumlah karya tulis yang telah disusun oleh Jalaluddin al-Suyuthi mencapai 500 judul dari berbagai bidang ilmu. Termasuk di dalamnya adalah bidang Hadīs diantaranya adalah Lubāb al-Hadīś, salahsatu karya tulisnya yang akan peneliti kaji.

\section{Definisi Kalām Khabari}

Kalām Khabari adalah bagian dari kajian ilmu ma'ani yang membahas mengenai makna-makna yang tersirat dari suatu kalimat/informasi. Dalam ilmu ma'ani terdapat dua kajian penting yaitu Kalām insya dan Kalām Khabar. Pada pembahasan ini, peneliti hanya akan fokus membahas definisi Kalām Khabari saja.

Kalām Khabar dalam bahasa Indonesia biasa disebut dengan kabar/berita. Abdurrahman al-Ahdhari (Abdurrahman al-Ahdhori 2009, 12) dalam kitab Jauhar al-Maknun bahwa Kalām Khabar adalah perkataan yang mungkin benar dan mungkin salah. Sementara menurut Ahmad Bachmid (Ahmad Bachdim 1996, 34) Kalām Khabar adalah pembicaraan yang mengandung kemungkinan benar atau dusta. Kebenaran khabar adalah kesesuaian antara perkataan dengan kejadiannya dan kebohongan khabar adalah ketidaksesuaian antara perkataan dengan keadiannya. Sebaliknya, jika perkataan yang tidak mengandung benar atau dusta, seperti kata "masuklah" atau "jangan Masuk" maka itu disebut Kalām insya.

Hampir semua ahli gramatika bahasa arab (terkhusus balaghah) senada dengan pendapat yang telah disebutkan, intinya Kalām Khabar adalah sebuah 
kalimat, ucapan, perkataan, atau pembicaraan yang pembicaranya bisa dikatakan benar atau salah dalam perkataanya tergantung sesuai atau tidak dengan keadaanya. Sebagai contoh singkat, Hasan berkata "Ahmad telah sampai di Rumah". Perkataan ini adalah Kalām Khabari, informasi ini bisa benar atau bisa saja salah tergantung keadaan sebenarnya, apakah Ahmad benar sampai atau belum di Rumah.

\section{Macam-macam Kalām Khabari}

Terbaginya Kalām Khabari dalam beberapa macam terjadi karena perbedaan mukhatab-nya (orang yang diajak bicara), ketika kondisi mukhatab-nya bermacam-macam, maka Kalām Khabar-nya terbagi menjadi tiga:

\section{1) Kalām Ibtidā'I}

Kalām Ibtidā'I terjadi ketika mukhatab dalam kondisi tidak mengetahui sama-sekali khabar yang dikatakan oleh si pembicara atau mukhatab tidak ragu dan tidak mengingkari informasi dari si pembicara, sehingga informasi yang disampaikan oleh si pembicara tanpa harus disertai dengan taukid (penguatan) (Al-Jarim and Amin 1999, 217). Seperti contoh kalimat berikut;

$$
\text { يا احمد، أنت ناجح في الامتحان }
$$

"Ahmad, kamu lulus dalam ujian"

$$
\text { ولا نشتذ جميعا فنحمل الناس على المهالك، ولكن نكون انت للشدة والغلظة. واكون أنا للرافة والرحة. }
$$

"Kita tidak boleh bersikap keras kepada siapapun, sebab yang demikian membawa kepada kehancuran. Sedangkan engkau berlaku kasar dan keras, dan aku berlaku lembut dan penuh kasih-sayang." (Al-Jarim and Amin 1999, 217).

Dari khabar di atas si pembicara hendak menjelaskan kepada mukhatab apa yang belum diketahuinya sama-sekali. Sehingga, si pembicara menyampaikan informasi tanpa mempertegasnya atau tanpa taukid (penguatan). Sehingga kalimat di atas disebut sebagai Kalām Khabar Ibtidā'I.

\section{2) Kalām Talabi}

Berbeda dengan Kalām Ibtidā'I yang mukhatab-nya tanpa ragu akan informasi yang diterima. Kalām Talabi terjadi ketika mukhatab ragu akan informasi yang diterimanya dari si pembicara. Mukhatab terkesan tidak akan menerima informasi dari si pembicara, sehingga si pembicara membutuhkan 
taukid untuk mempertegas perkataannya. Ali al-Jarim (Al-Jarim and Amin 1999, 219) menjelaskan bahwa Kalām Talabi adalah ketika mukhatab ragu akan informasi tersebut dan butuh taukid atau ketegasan untuk membenarkan informasi tersebut. Berikut contoh kalimatnya:

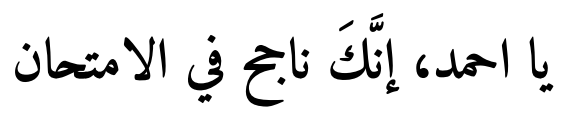

"Ahmad, sungguh kamu lulus dalam ujian"

Pada contoh kalimat di atas, si pembicara ingin memberikan informasi dengan taukid (penguatan), karena si pembicara merasa perlu memberi ketegasan informasinya agar mukhatab tidak ragu dengan khabar yang disampaikannya.

\section{3) Kalām Inkāri}

Lebih jelas lagi, Kalām Inkāri terjadi ketika mukhatab mengingkari khabar (informasi) yang diterimanya dari si pembicara. Pada kondisi ini, si pembicara wajib menegaskan atau menambahkan taukid dalam khabarnya sesuai dengan pengingkaran mukhatab (Al-Jarim and Amin 1999, 220). Dari pengertian itu, jelas bahwa jika mukhatab mengingkari khabar si pembicara, maka si pembicara harus menambahkan kalimat penguat lebih dari satu, apabila frekuensi pengingkarannya sudah sangat fatal. Perhatikan rangkaian penguat dalam kalimat berikut:

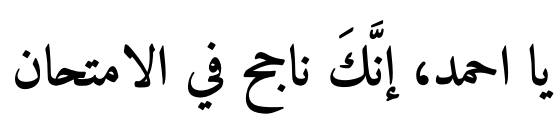

"Ahmad, sungguh kamu lulus dalam ujian"

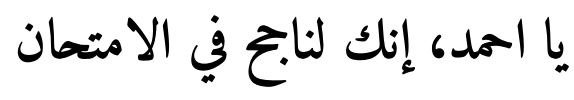

"Ahmad, sungguh-sungguh kamu lulus dalam ujian"

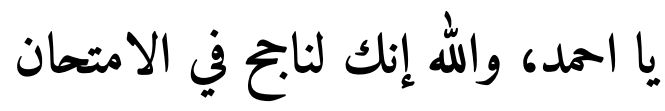

"Ahmad, demi Allah sungguh-sungguh kamu lulus dalam ujian"

Pada kalimat pertama, jika mukhatab ingkar maka menggunakan satu tauqid (إنَّ). Pada kalimat kedua, jika mukhatab mengingkari, maka menggunakan 
dua tauqid (إنَّ + ل ل). Pada kalimat ketiga, jika mukhatab masih mengingkari, maka menggunakan tiga tauqid (إنَّ + ل + والذّ).

Tauqid ini berfungsi sebagai penguat agar mukhatab menerima khabar dan menghilangkan pengingkarannya. Penambahan tauqid harus disesuaikan dengan frekuensi pengingkarannya. Oleh karenanya pada contoh pertama masih menggunakan satu tauqid, ketika masih mengingkari maka menggunakan dua tauqid, apabila masih maka menggunakan tiga tauqid (qasam, inna, lam ibtida).

\section{Metode Penelitian}

Metode penelitian yang digunakan peneliti dalam penelitian ini adalah metode studi literatur (literature study), yang merupakan serangkaian kegiatan yang berkenaan dengan metode pengumpulan data pustaka, membaca mencatat, kemudian mengolah bahan penelitian (Diah 2019). Referensinya diperoleh melalui laporan penelitian khususnya yang sudah terpublikasi, jurnal, artikel, buku, atau situs-situs di internet yang berbobot. Metodologi sendiri bermakna proses, prinsip, dan prosedur yang kita gunakan untuk mendekati problem dan mencari jawaban" (Mulyana 2008, 145). Sehingga penelitian ini mencoba menjelaskan dan menguraikan Kalām Khabari dan macam-macamnya yang terdapat dalam kitab Lubāb al-Hadīs. Kitab Lubāb al-Hadīs terdiri dari 40 bab, pada setiap bab-nya memuat 10 Hadīs dengan keseluruahnnya 400 Hadīs. Namun dalam penelitian ini, peneliti mengambil sampel satu Hadīs dari setiap bab-nya.

Adapun prosedurnya melalui tiga tahap, yaitu; (1) Sumber data dan pengumpulan data tentang Hadīs-Hadīs yang terdapat pada kitab Lubāb al-Hadīs (2) analisis data, dan (3) Penyajian hasil data macam-macam Kalām Khabari yang terkandung dalam kitab Lubāb al-Hadīs;;

\section{Hasil dan Pembahasan}

Sesuai dengan tujuan penelitian ini yaitu menganalisis Hadīs pada kitab Lubāb al-Hadīs dengan pendekatan balaghah, sehingga peneliti menemukan beberapa Hadīs yang menggunakan gaya bahasa Kalām Khabar Ibtidā'I, Talabi dan tidak ditemukan Kalām Khabar Inkāri. Tentunya, informasi Hadīs yang menggunakan Kalām Khabar ini juga dapat menentukan siapa mukhatab dalam 
pembicaraan tersebut. Sesuai dengan judul penelitian di atas, Hadīś-Hadīs yang termasuk dalam Kalām Khabari adalah sebagai berikut:

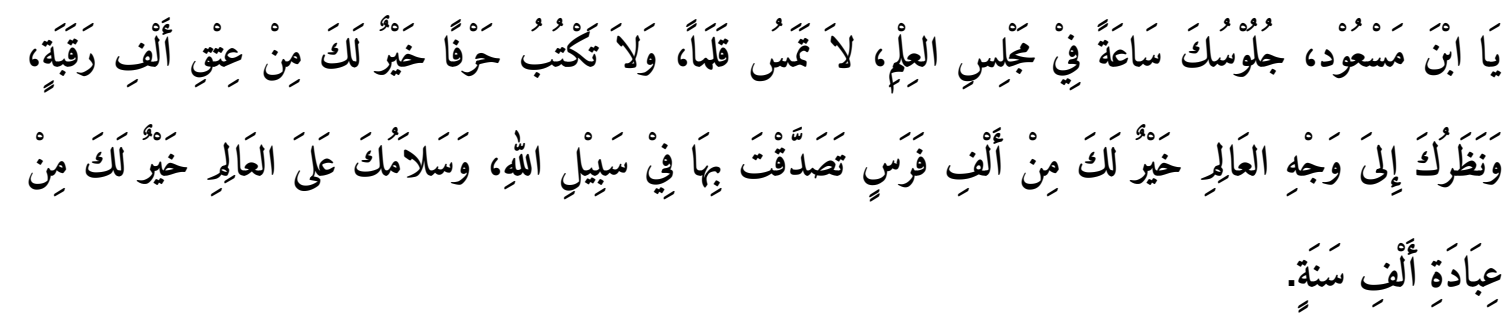

Hadīs di atas terdapat tiga jenis Kalām Khabari Ibtidā'I, karena tidak adanya perangkat taukid (penegasan), mengapa demikian? Karena mukhatab-nya khāliż żihni (belum tahu sedikitpun tentang informasi yang didengar) terhadap khabar yang diterimanya. Adapun ghardh al-Kalām atau tujuannya adalah fāidatul khabar (menyampaikan maksud yang terkandung dalam suatu kalimat kepada mukhatab) bahwa pentingnya menuntut ilmu dan seorang 'alim.

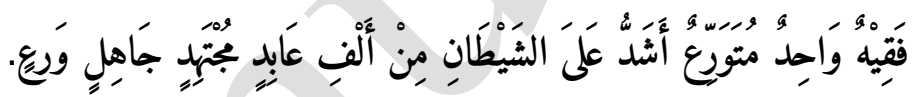

Hadīs di atas merupakan Kalām Khabari Ibtidā'I, karena tidak adanya perangkat taukid (penegasan), mengapa demikian? Karena mukhatab-nya khāliż żihni (belum tahu sedikitpun tentang informasi yang didengar) terhadap khabar yang diterimanya. Adapun ghardh al-Kalām atau tujuannya adalah fāidatul khabar (menyampaikan maksud yang terkandung dalam suatu kalimat kepada mukhatab) bahwa seorang yang 'alim yang shaleh lebih sulit bagi setan untuk digoda daripada 1000 abid shaled dan sungguh-sungguh tapi awam.

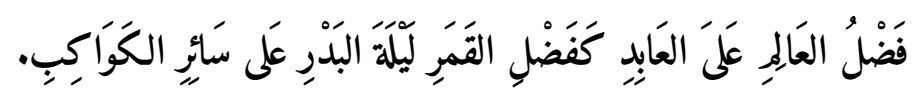

Hadīs di atas merupakan Kalām Khabari Ibtidā'I, karena tidak adanya perangkat taukid (penegasan), mengapa demikian? Karena mukhatab-nya khāliżżihni (belum tahu sedikitpun tentang informasi yang didengar) terhadap khabar yang diterimanya. Adapun ghardh al-Kalām atau tujuannya adalah fāidatul khabar (menyampaikan maksud yang terkandung dalam suatu kalimat kepada mukhatab) bahwa seorang 'alim dengan awam seperti bulan purnama dan bintang-bintang.

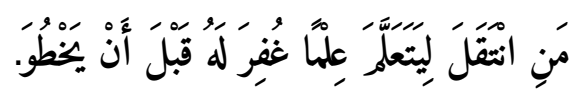

Hadīs di atas merupakan Kalām Khabari Ibtidā'I, karena tidak adanya perangkat taukid (penegasan), mengapa demikian? Karena mukhatab-nya khāliż 
żihni (belum tahu sedikitpun tentang informasi yang didengar) terhadap khabar yang diterimanya. Adapun ghardh al-Kalām atau tujuannya adalah fāidatul khabar (menyampaikan maksud yang terkandung dalam suatu kalimat kepada mukhatab) bahwa siapa saja hendak pergi menuntut ilmu, sebelum kedua kakinya melangkah sudah diampuni dosa-dosanya.

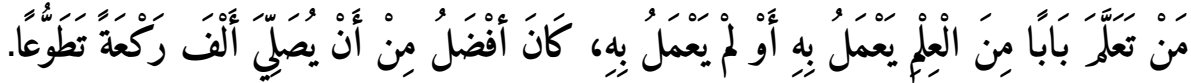

Hadīs di atas merupakan Kalām Khabari Ibtidā'I, karena tidak adanya perangkat taukid (penegasan), mengapa demikian? Karena mukhatab-nya khāliż żihni (belum tahu sedikitpun tentang informasi yang didengar) terhadap khabar yang diterimanya. Adapun ghardh al-Kalām atau tujuannya adalah fāidatul khabar (menyampaikan maksud yang terkandung dalam suatu kalimat kepada mukhatab) bahwa belajar satu bab ilmu lebih utama dari shalat sunah 1000 rakaat yang ikhlas.

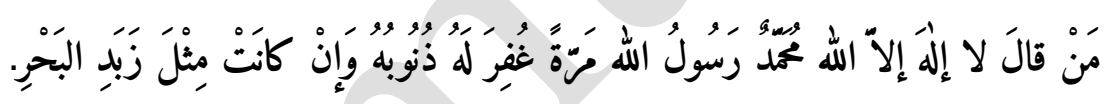

Hadīs di atas merupakan Kalām Khabari Ibtidā'I, karena tidak adanya perangkat taukid (penegasan), mengapa demikian? Karena mukhatab-nya khāliż żihni (belum tahu sedikitpun tentang informasi yang didengar) terhadap khabar yang diterimanya. Adapun ghardh al-Kalām atau tujuannya adalah fāidatul khabar (menyampaikan maksud yang terkandung dalam suatu kalimat kepada mukhatab) bahwa seorang yang mengucap lafazh tersebut akan diampuni dosa-dosanya meski sebanyak buih lautan.

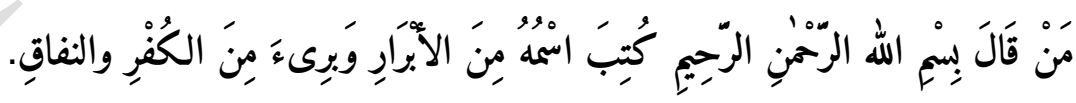

Hadīs di atas merupakan Kalām Khabari Ibtidā'I, karena tidak adanya perangkat taukid (penegasan), mengapa demikian? Karena mukhatab-nya khāliż żihni (belum tahu sedikitpun tentang informasi yang didengar) terhadap khabar yang diterimanya. Adapun ghardh al-Kalām atau tujuannya adalah fāidatul khabar (menyampaikan maksud yang terkandung dalam suatu kalimat kepada mukhatab) bahwa siapapun yang memperbanyak mengucapkan basmalah supaya dicatat sebagai orang taat dan terbebas dari kekufuran dan nifaq.

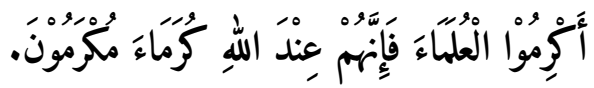


Hadīs di atas merupakan Kalām Khabari Talabi, karena adanya perangkat taukid (إنَّ), mengapa demikian? Karena mukhatab-nya mutaraddid (ragu, sehingga perlu penegasan) terhadap khabar yang diterimanya. Adapun ghardh al-Kalām atau tujuannya adalah fäidatul khabar (menyampaikan maksud yang terkandung dalam suatu kalimat kepada mukhatab) bahwa sungguh ulama adalah manusia yang mendapatkan kemuliaan dari Allah swt.

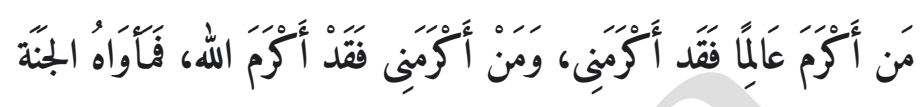

Hadīs di atas merupakan Kalām Khabari Talabi, karena adanya perangkat taukid (قَ), mengapa demikian? Karena mukhatab-nya mutaraddid (ragu, sehingga perlu penegasan) terhadap khabar yang diterimanya. Adapun ghardh al-Kalām atau tujuannya adalah fãidatul khabar (menyampaikan maksud yang terkandung dalam suatu kalimat kepada mukhatab) bahwa ada penegasan dalam kalimat siapa saja yang memuliakan seorang 'alim seperti memuliakan Nabis saw., dan siapa yang memuliakan Nabi saw., maka sungguh telah memuliakan Allah SWT.

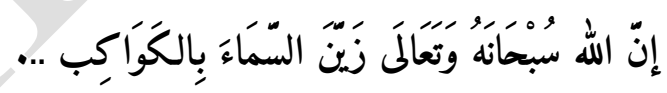

Hadīs di atas merupakan Kalām Khabari Talabi, karena adanya perangkat taukid (إنَّ), mengapa demikian? Karena mukhatab-nya mutaraddid (ragu, sehingga perlu penegasan) terhadap khabar yang diterimanya. Adapun ghardh al-Kalām atau tujuannya adalah fāidatul khabar (menyampaikan maksud yang terkandung dalam suatu kalimat kepada mukhatab) bahwa sungguh langit itu adalah ciptaan Allah dan Dia telah menghiasinya dengan bintang-bintang.

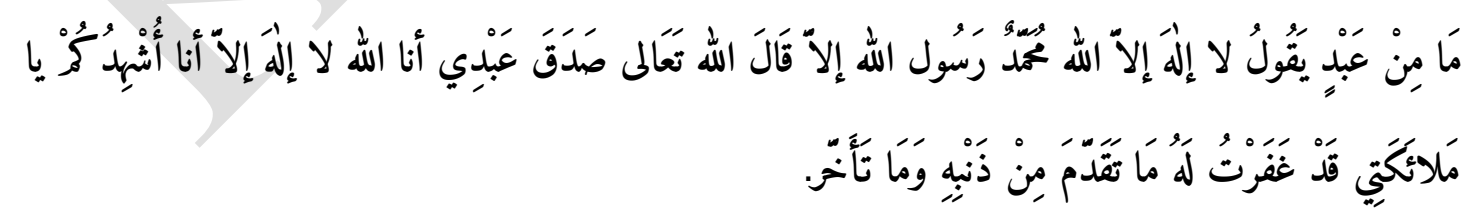

Hadīs di atas merupakan Kalām Khabari Ṭalabi, karena adanya perangkat taukid (فَ), mengapa demikian? Karena mukhatab-nya mutaraddid (ragu, sehingga perlu penegasan) terhadap khabar yang diterimanya. Adapun ghardh al-Kalām atau tujuannya adalah fãidatul khabar (menyampaikan maksud yang terkandung dalam suatu kalimat kepada mukhatab) bahwa seorang hamba yang mengucapkan lafazh tersebut sungguh akan diampuni dosa sebelumnya dan yang akan datang. 
Kalamuna, Vol. 3. No. 1, Januari 2022. 81 - 104

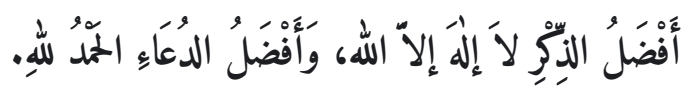

Hadīs di atas merupakan Kalām Khabari Ibtidā'I, karena tidak adanya perangkat taukid (penegasan), mengapa demikian? Karena mukhatab-nya khāliż żihni (belum tahu sedikitpun tentang informasi yang didengar) terhadap khabar yang diterimanya. Adapun ghardh al-Kalām atau tujuannya adalah fāidatul khabar (menyampaikan maksud yang terkandung dalam suatu kalimat kepada mukhatab) yaitu mengedukasi mukhothob tentang keutamaan dzikir yang dimaksud dan doa sebagai wujud lain dari dzikrullah.

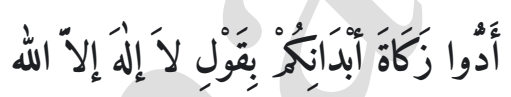

Hadīs di atas merupakan Kalām Khabari Ibtidā'I, karena tidak adanya perangkat taukid (penegasan), mengapa demikian? Karena mukhatab-nya khāliż żihni (belum tahu sedikitpun tentang informasi yang didengar) terhadap khabar yang diterimanya. Adapun ghardh al-Kalām atau tujuannya adalah fāidatul khabar (menyampaikan maksud yang terkandung dalam suatu kalimat kepada mukhatab) yaitu anjuran hukum keutamaan dzikir laa ilaha illallah yang diposisikan menyamai ibadah sedekah secara fisik dengan mengucapkannya sama dengan bersedakah/zakat.

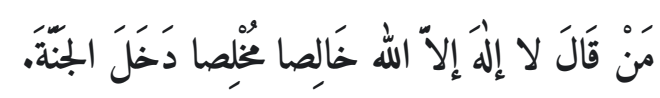

Hadīs di atas merupakan Kalām Khabari Ibtidā'I, karena tidak adanya perangkat taukid (penegasan), mengapa demikian? Karena mukhatab-nya khāliż żihni (belum tahu sedikitpun tentang informasi yang didengar) terhadap khabar yang diterimanya. Adapun ghardh al-Kalām atau tujuannya adalah fāidatul khabar (menyampaikan maksud yang terkandung dalam suatu kalimat kepada mukhatab) bahwa yang mengucapkan laa ilaha illallah dengan ikhlas, tidak disertai riya, maka dijamin masuk surga.

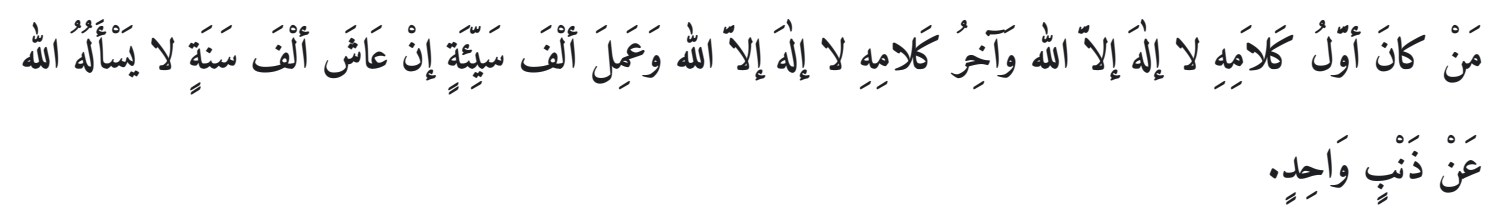

Hadīs di atas merupakan Kalām Khabari Ibtidā'I, karena tidak adanya perangkat taukid (penegasan), mengapa demikian? Karena mukhatab-nya khāliż 
żihni (belum tahu sedikitpun tentang informasi yang didengar) terhadap khabar yang diterimanya. Adapun ghardh al-Kalām atau tujuannya adalah fāidatul khabar (menyampaikan maksud yang terkandung dalam suatu kalimat kepada mukhatab) bahwa orang yang mengucap laa ilaha illallah di awal dan di akhir pembicaraannya maka akan diampuni dosanya sebanyak apapun.

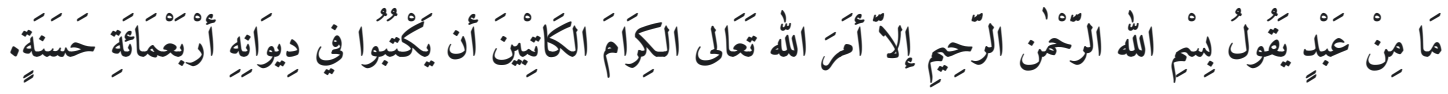

Hadīs di atas merupakan Kalām Khabari Ibtidā'I, karena tidak adanya perangkat taukid (penegasan), mengapa demikian? Karena mukhatab-nya khāliż żihni (belum tahu sedikitpun tentang informasi yang didengar) terhadap khabar yang diterimanya. Adapun ghardh al-Kalām atau tujuannya adalah fāidatul khabar (menyampaikan maksud yang terkandung dalam suatu kalimat kepada mukhatab) agar mukhotob bersungguh-sungguh dengan memperbanyak membaca basmalah agar mendapat catatan sebanyak 400 kebaikan.

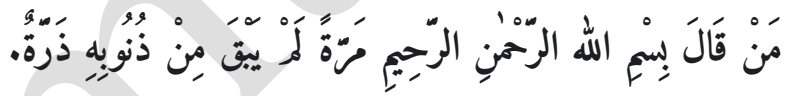

Hadīs di atas merupakan Kalām Khabari Ibtidā'I, karena tidak adanya perangkat taukid (penegasan), mengapa demikian? Karena mukhatab-nya khāliż żihni (belum tahu sedikitpun tentang informasi yang didengar) terhadap khabar yang diterimanya. Adapun ghardh al-Kalām atau tujuannya adalah fāidatul khabar (menyampaikan maksud yang terkandung dalam suatu kalimat kepada mukhatab) bahwa keutamaan mengucapkan basmalah dapat menghapus dosa-dosa, maka perbanyaklah membaca dzikir tersebut.

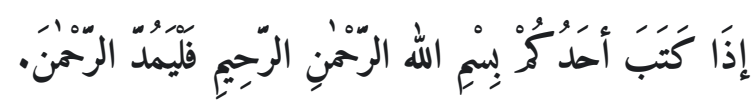

Hadīs di atas merupakan Kalām Khabari Ibtidā'I, karena tidak adanya perangkat taukid (penegasan), mengapa demikian? Karena mukhatab-nya khāliż żihni (belum tahu sedikitpun tentang informasi yang didengar) terhadap khabar yang diterimanya. Adapun ghardh al-Kalām atau tujuannya adalah fāidatul khabar (menyampaikan maksud yang terkandung dalam suatu kalimat kepada mukhatab) adalah menyampaikan hukum kepada mukhotob agar memperbaiki tulisan basmalah, ketika hendak menuliskannya maka panjangkan lafazh Ar-Rahman 
huruf lam dan huruf miim dan melengkungkan huruf nuun, maksudnya dengan memperindah tulisan sebagai pengagungan terhadap kebesaran Allah SWT.

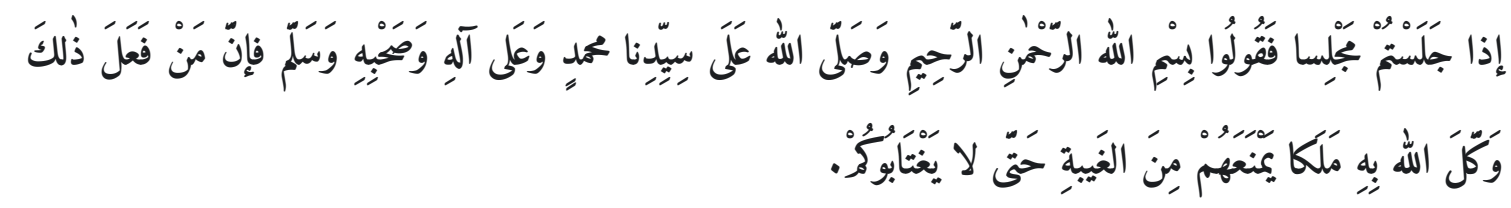

Hadīs di atas merupakan Kalām Khabari Ibtidā'I, karena tidak adanya perangkat taukid (penegasan), mengapa demikian? Karena mukhatab-nya khāliż żihni (belum tahu sedikitpun tentang informasi yang didengar) terhadap khabar yang diterimanya. Adapun ghardh al-Kalām atau tujuannya adalah fāidatul khabar (menyampaikan maksud yang terkandung dalam suatu kalimat kepada mukhatab) bahwa malaikat ditugaskan mencegah orang lain untuk tidak menggunjing orang yang berdzikir dengan bacaan ini.

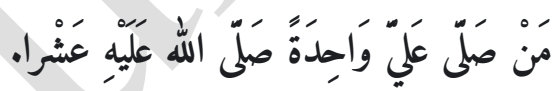

Hadīs di atas merupakan Kalām Khabari Ibtidā'I, karena tidak adanya perangkat taukid (penegasan), mengapa demikian? Karena mukhatab-nya khāliż żihni (belum tahu sedikitpun tentang informasi yang didengar) terhadap khabar yang diterimanya. Adapun ghardh al-Kalām atau tujuannya adalah fāidatul khabar (menyampaikan maksud yang terkandung dalam suatu kalimat kepada mukhatab) bahwa setiap kali mukhotob membaca satu kali shalawat kepada Nabi saw., maka Allah SWT melipatgandakan rahmat-Nya 10 kali.

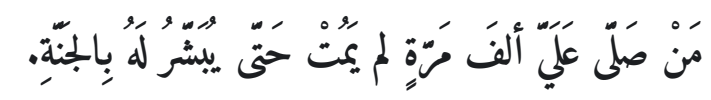

Hadīs di atas merupakan Kalām Khabari Ibtidā'I, karena tidak adanya perangkat taukid (penegasan), mengapa demikian? Karena mukhatab-nya khāliż żihni (belum tahu sedikitpun tentang informasi yang didengar) terhadap khabar yang diterimanya. Adapun ghardh al-Kalām atau tujuannya adalah fāidatul khabar (menyampaikan maksud yang terkandung dalam suatu kalimat kepada mukhatab) bahwa siapa saja yang membaca shalawat sebanyak 100 kali, maka tidak akan mati kecuali dia diperlihatkan surga.

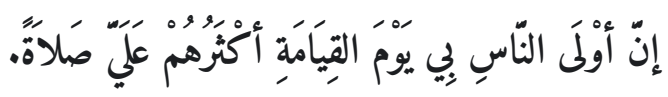


Hadīs di atas merupakan Kalām Khabari Talabi, karena adanya perangkat taukid (إنَّ), mengapa demikian? Karena mukhatab-nya mutaraddid (ragu, sehingga perlu penegasan) terhadap khabar yang diterimanya. Adapun ghardh al-Kalām atau tujuannya adalah fāidatul khabar (menyampaikan maksud yang terkandung dalam suatu kalimat kepada mukhatab) bahwa orang yang banyak bershalawat akan tinggi kedudukannya di hari kiamat.

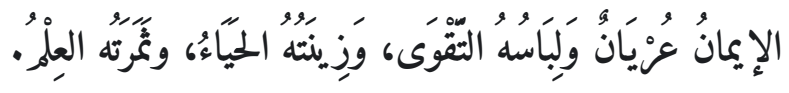

Hadīs di atas merupakan Kalām Khabari Ibtidā'I, karena tidak adanya perangkat taukid (penegasan), mengapa demikian? Karena mukhatab-nya khāliż żihni (belum tahu sedikitpun tentang informasi yang didengar) terhadap khabar yang diterimanya. Adapun ghardh al-Kalām atau tujuannya adalah fāidatul khabar (menyampaikan maksud yang terkandung dalam suatu kalimat kepada mukhatab) bahwa pakaian keimanan itu adalah takwa, perhiasannya adalah rasa malu dan buahnya adalah ilmu.

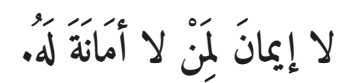

Hadīs di atas merupakan Kalām Khabari Ibtidā'I, karena tidak adanya perangkat taukid (penegasan), mengapa demikian? Karena mukhatab-nya khāliż żihni (belum tahu sedikitpun tentang informasi yang didengar) terhadap khabar yang diterimanya. Adapun ghardh al-Kalām atau tujuannya adalah fāidatul khabar (menyampaikan maksud yang terkandung dalam suatu kalimat kepada mukhatab) bahwa tidak memiliki iman bagi orang yang tidak amanah.

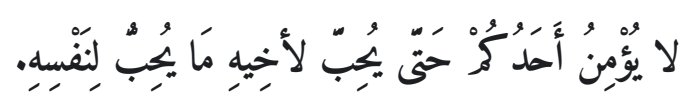

Hadīs di atas merupakan Kalām Khabari Ibtidā'I, karena tidak adanya perangkat taukid (penegasan), mengapa demikian? Karena mukhatab-nya khāliż żihni (belum tahu sedikitpun tentang informasi yang didengar) terhadap khabar yang diterimanya. Adapun ghardh al-Kalām atau tujuannya adalah fāidatul khabar (menyampaikan maksud yang terkandung dalam suatu kalimat kepada mukhatab) bahwa belum beriman bagi seseorang yang tidak mencintai saudaranya seperti mencintai dirinya sendiri.

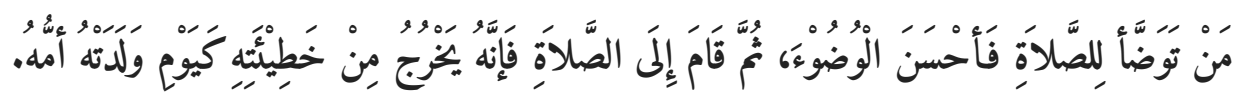


Hadīs di atas merupakan Kalām Khabari Ibtidā'I, karena tidak adanya perangkat taukid (penegasan), mengapa demikian? Karena mukhatab-nya khāliż żihni (belum tahu sedikitpun tentang informasi yang didengar) terhadap khabar yang diterimanya. Adapun ghardh al-Kalām atau tujuannya adalah fāidatul khabar (menyampaikan maksud yang terkandung dalam suatu kalimat kepada mukhatab) bahwa siapa saja yang berwudhu dengan baik, kemudian melaksanakan shalat, maka ia akan keluar dari kesalahannya seperti hari dimana ia dilahirkan ibunya.

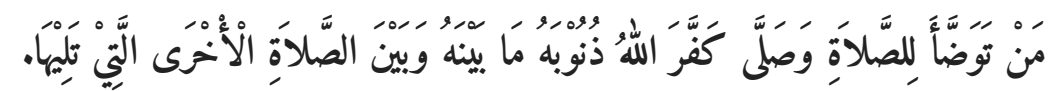

Hadīs di atas merupakan Kalām Khabari Ibtidā'I, karena tidak adanya perangkat taukid (penegasan), mengapa demikian? Karena mukhatab-nya khāliż żihni (belum tahu sedikitpun tentang informasi yang didengar) terhadap khabar yang diterimanya. Adapun ghardh al-Kalām atau tujuannya adalah fāidatul khabar (menyampaikan maksud yang terkandung dalam suatu kalimat kepada mukhatab) bahwa siapa saja yang berwudhu untuk shalat dan melaksanakan shalat, maka Allah akan melebur dosa-dosanya (yang kecil) antara shalat itu dengan shalat yang lainnya.

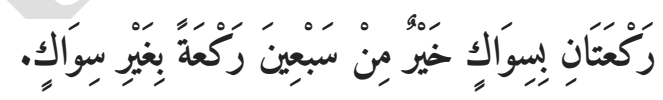

Hadīs di atas merupakan Kalām Khabari Ibtidā'I, karena tidak adanya perangkat taukid (penegasan), mengapa demikian? Karena mukhatab-nya khāliż żihni (belum tahu sedikitpun tentang informasi yang didengar) terhadap khabar yang diterimanya. Adapun ghardh al-Kalām atau tujuannya adalah fāidatul khabar (menyampaikan maksud yang terkandung dalam suatu kalimat kepada mukhatab) bahwa shalat dengan membersihkan mulut (siwak) lebih utama.

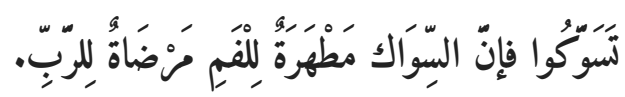

Hadīś di atas merupakan Kalām Khabari Talabi, karena adanya perangkat taukid (إنَّ), mengapa demikian? Karena mukhatab-nya mutaraddid (ragu, sehingga perlu penegasan) terhadap khabar yang diterimanya. Adapun ghardh al-Kalām atau tujuannya adalah fāidatul khabar (menyampaikan maksud yang terkandung dalam suatu kalimat kepada mukhatab) bahwa ada penegasan dalam menjelaskan siwak yang dapat membersihkan mulut.

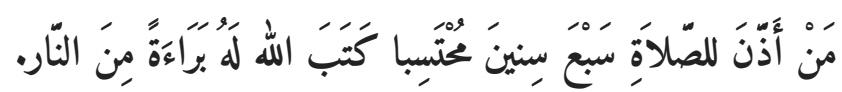


Hadīs di atas merupakan Kalām Khabari Ibtidā'I, karena tidak adanya perangkat taukid (penegasan), mengapa demikian? Karena mukhatab-nya khāliż żihni (belum tahu sedikitpun tentang informasi yang didengar) terhadap khabar yang diterimanya. Adapun ghardh al-Kalām atau tujuannya adalah fāidatul khabar (menyampaikan maksud yang terkandung dalam suatu kalimat kepada mukhatab) bahwa siapa saja yang secara konsisten selama 7 tahun adzan dengan ikhlas, maka Allah menetapkannya bebas dari siksa neraka.

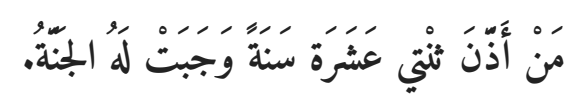

Hadīs di atas merupakan Kalām Khabari Ibtidā'I, karena tidak adanya perangkat taukid (penegasan), mengapa demikian? Karena mukhatab-nya khāliż żihni (belum tahu sedikitpun tentang informasi yang didengar) terhadap khabar yang diterimanya. Adapun ghardh al-Kalām atau tujuannya adalah fāidatul khabar (menyampaikan maksud yang terkandung dalam suatu kalimat kepada mukhatab) bahwa siapa saja yang secara konsisten selama 12 tahun adzan dengan ikhlas, maka wajb baginya surga.

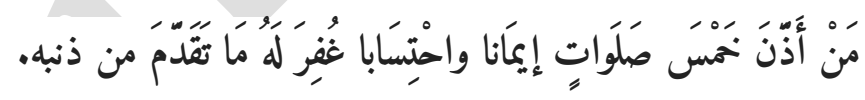

Hadīs di atas merupakan Kalām Khabari Ibtidā'I, karena tidak adanya perangkat taukid (penegasan), mengapa demikian? Karena mukhatab-nya khāliż żihni (belum tahu sedikitpun tentang informasi yang didengar) terhadap khabar yang diterimanya. Adapun ghardh al-Kalām atau tujuannya adalah fāidatul khabar (menyampaikan maksud yang terkandung dalam suatu kalimat kepada mukhatab) bahwa siapa saja yang adzan dalam 5 waktu shalat karena iman dan ikhlas, maka diampuni dosa-dosanya yang suah terlewat.

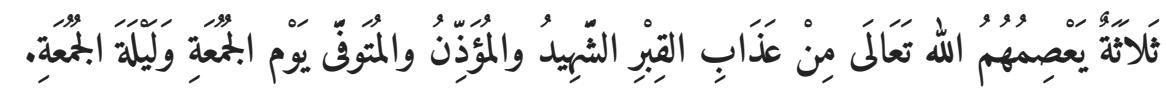

Hadīs di atas merupakan Kalām Khabari Ibtidā'I, karena tidak adanya perangkat taukid (penegasan), mengapa demikian? Karena mukhatab-nya khāliż żihni (belum tahu sedikitpun tentang informasi yang didengar) terhadap khabar yang diterimanya. Adapun ghardh al-Kalām atau tujuannya adalah fāidatul khabar (menyampaikan maksud yang terkandung dalam suatu kalimat kepada mukhatab) 
bahwa ada tiga macam manusia yang dijaga dari siksa kubur: syahid, mu`adzin, dan orang yang wafat pada malam atau hari jum`at .

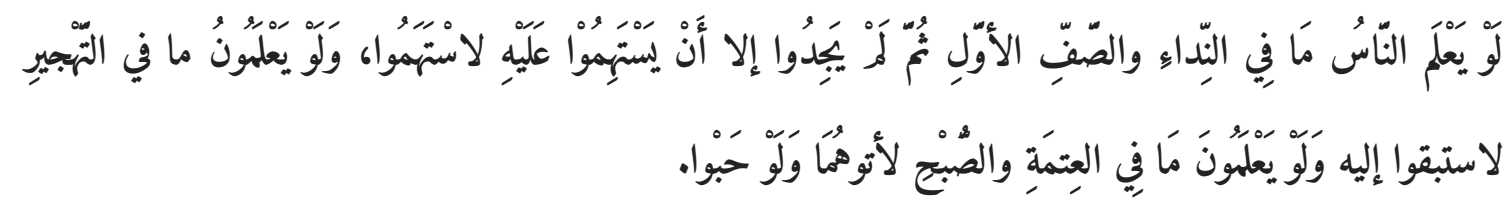

Hadīs di atas merupakan Kalām Khabari Ibtidā'I, karena tidak adanya perangkat taukid (penegasan), mengapa demikian? Karena mukhatab-nya khāliż żihni (belum tahu sedikitpun tentang informasi yang didengar) terhadap khabar yang diterimanya. Adapun ghardh al-Kalām atau tujuannya adalah fāidatul khabar (menyampaikan maksud yang terkandung dalam suatu kalimat kepada mukhatab) bahwa jika seseorang tahu yang ada dalam seruan adzan dan pentingnya berjamaah isya dan subuh, niscaya dia akan mendatanginya walaupun dengan merangkak.

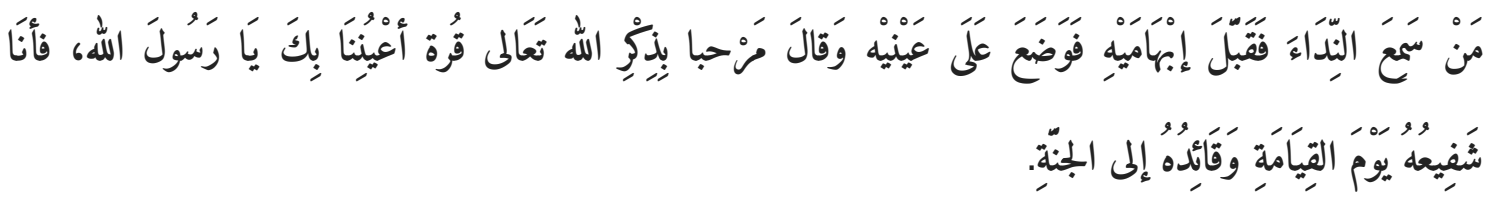

Hadīs di atas merupakan Kalām Khabari Ibtidā'I, karena tidak adanya perangkat taukid (penegasan), mengapa demikian? Karena mukhatab-nya khāliż żihni (belum tahu sedikitpun tentang informasi yang didengar) terhadap khabar yang diterimanya. Adapun ghardh al-Kalām atau tujuannya adalah fāidatul khabar (menyampaikan maksud yang terkandung dalam suatu kalimat kepada mukhatab) bahwa ketika seseorang mendengar adzan kemudian mencium kedua ibu jarinya,

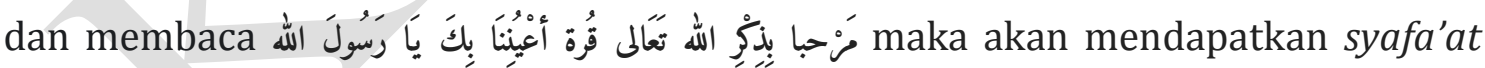
Nabi saw.

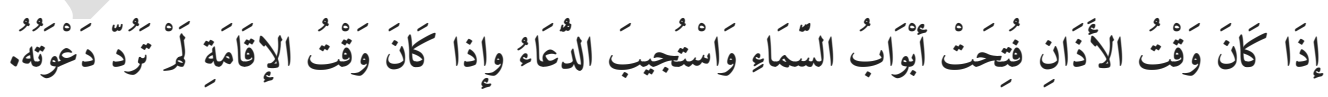

Hadīs di atas merupakan Kalām Khabari Ibtidā'I, karena tidak adanya perangkat taukid (penegasan), mengapa demikian? Karena mukhatab-nya khāliż żihni (belum tahu sedikitpun tentang informasi yang didengar) terhadap khabar yang diterimanya. Adapun ghardh al-Kalām atau tujuannya adalah fāidatul khabar (menyampaikan maksud yang terkandung dalam suatu kalimat kepada mukhatab) bahwa ketika waktu adzan tiba pintu-pintu langit dibuka dan doa dikabulkan, 
kemudian ketika waktu iqamat tiba dan seseorang berdoa, maka doanya tidak tertolak.

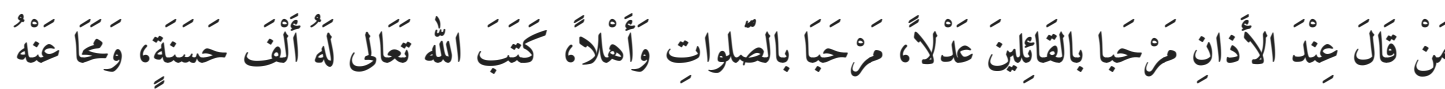

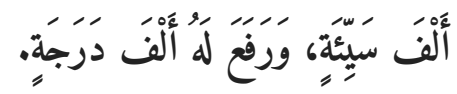

Hadīs di atas merupakan Kalām Khabari Ibtidā'I, karena tidak adanya perangkat taukid (penegasan), mengapa demikian? Karena mukhatab-nya khāliż żihni (belum tahu sedikitpun tentang informasi yang didengar) terhadap khabar yang diterimanya. Adapun ghardh al-Kalām atau tujuannya adalah fāidatul khabar (menyampaikan maksud yang terkandung dalam suatu kalimat kepada mukhatab)

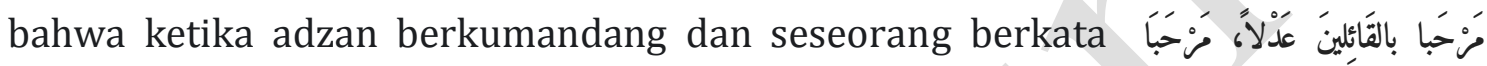
maka Allah menetapkan baginya seribu kebaikan dan menghapus seribu keburukan.

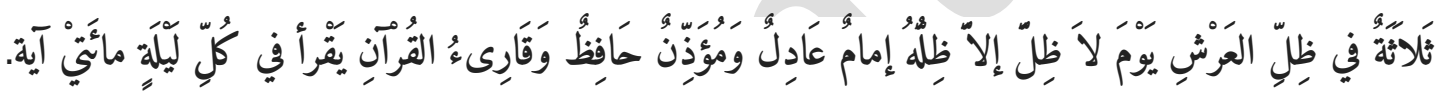

Hadīs di atas merupakan Kalām Khabari Ibtidā'I, karena tidak adanya perangkat taukid (penegasan), mengapa demikian? Karena mukhatab-nya khāliż żihni (belum tahu sedikitpun tentang informasi yang didengar) terhadap khabar yang diterimanya. Adapun ghardh al-Kalām atau tujuannya adalah fāidatul khabar (menyampaikan maksud yang terkandung dalam suatu kalimat kepada mukhatab) bahwa tiga macam manusia yang ada dalam naungan-Nya: pemimpin adil, muadzin yang konsisten, dan seseorang yang membaca al-Qur'an 200 ayat setiap malamnya.

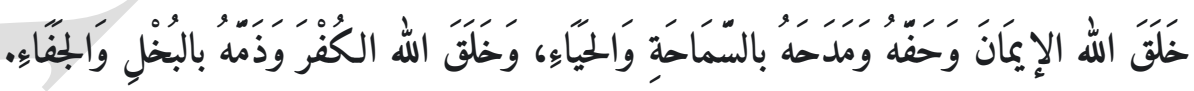

Hadīs di atas merupakan Kalām Khabari Ibtidā'I, karena tidak adanya perangkat taukid (penegasan), mengapa demikian? Karena mukhatab-nya khāliż żihni (belum tahu sedikitpun tentang informasi yang didengar) terhadap khabar yang diterimanya. Adapun ghardh al-Kalām atau tujuannya adalah fāidatul khabar (menyampaikan maksud yang terkandung dalam suatu kalimat kepada mukhatab) bahwa Allah menciptakan Iman dan menghiasinya dan memujinya dengan murah hati dan rasa malu, kemudian Allah menciptakan kufur dan mencelanya dengan bakhil dan durhaka. 
Kalamuna, Vol. 3. No. 1, Januari 2022. 81 - 104

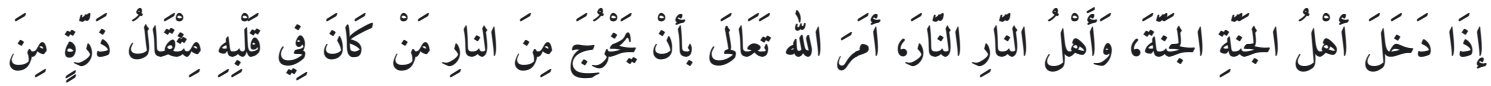
الإِيْمَنِ.

Hadīs di atas merupakan Kalām Khabari Ibtidā'I, karena tidak adanya perangkat taukid (penegasan), mengapa demikian? Karena mukhatab-nya khāliż żihni (belum tahu sedikitpun tentang informasi yang didengar) terhadap khabar yang diterimanya. Adapun ghardh al-Kalām atau tujuannya adalah fāidatul khabar (menyampaikan maksud yang terkandung dalam suatu kalimat kepada mukhatab) bahwa ketika penghuni surga telah masuk ke surga dan penghuni neraka telah masuk ke neraka, Allah memererintahkan agar mengeluarkan orang-orang dari neraka apabila ada dalam hatinya iman walaupun sebesar atom.

Dari 400 Hadīs dalam 40 bab, diambil 40 Hadīs sebagai sampel pada penelitian ini. Berikut hasil analisis dalam tabel:

\begin{tabular}{|c|c|c|c|c|}
\hline NO & REDAKSI HADĪS & JENIS & TAUKID & TUJUAN KHABAR \\
\hline 1. & 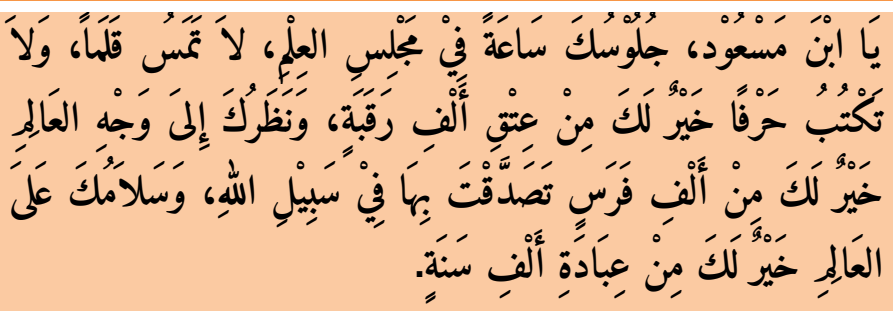 & Ibtidā'I & - & Fāidatul Khabar \\
\hline 2. & 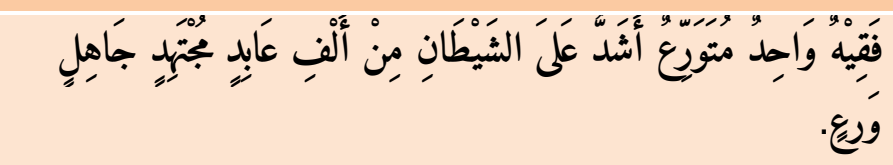 & Ibtidā'I & - & Fāidatul Khabar \\
\hline 3. & 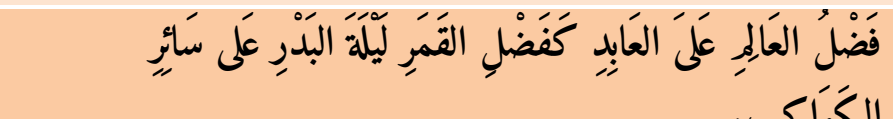 & Ibtidā'I & - & Fāidatul Khabar \\
\hline 4. & 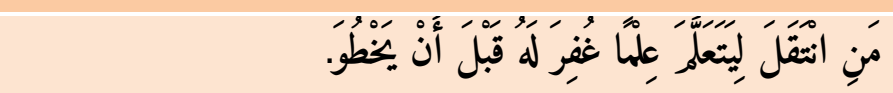 & Ibtidā'I & - & Fāidatul Khabar \\
\hline 5. & 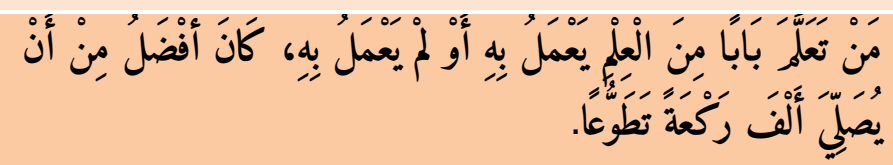 & Ibtidā'I & - & Fāidatul Khabar \\
\hline 6. & 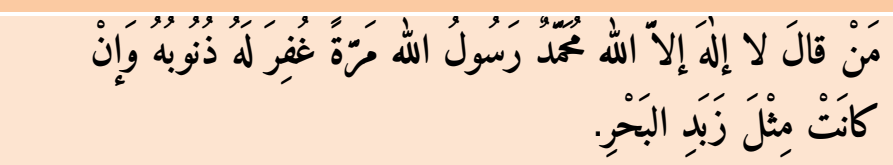 & Ibtidā'I & - & Fāidatul Khabar \\
\hline
\end{tabular}


Analisis Kalām Khabari... (Ahmad Fajar \& Taufik Luthfi)

\begin{tabular}{|c|c|c|c|c|}
\hline 7. & 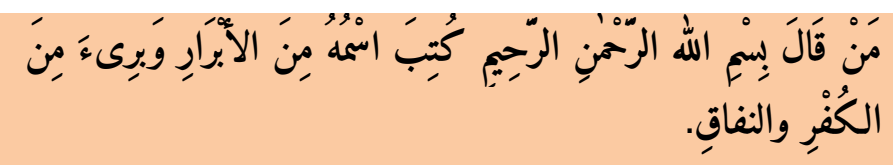 & Ibtidā'I & - & Fāidatul Khabar \\
\hline 8. & كُوَمَاءَ مُكُكَمْوْنَ. & Talabi & إنَّ & Fāidatul Khabar \\
\hline 9. & 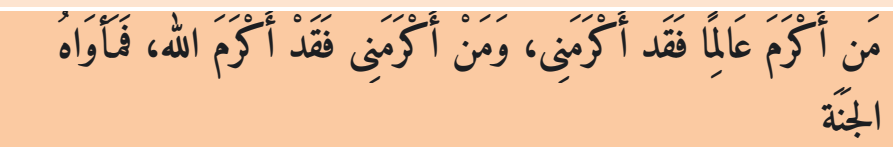 & Talabi & قََْْ & Fāidatul Khabar \\
\hline 10. & بِالكَوَاَكِب ... & Talabi & إنَّ & Fāidatul Khabar \\
\hline 11. & 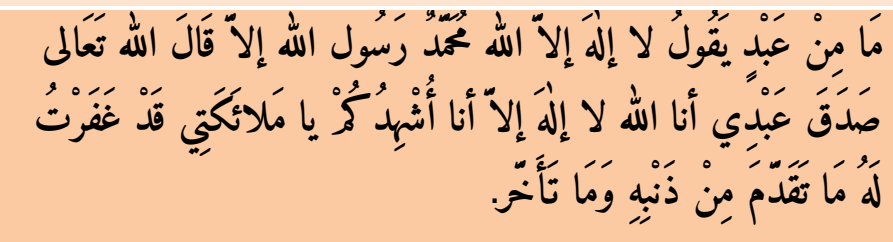 & Ṭalabi & قَقْْ & Fāidatul Khabar \\
\hline 12. & لَ الدَعَاء الحمَّدُ للهِه. & Ibtidā'I & - & Fāidatul Khabar \\
\hline 13. & 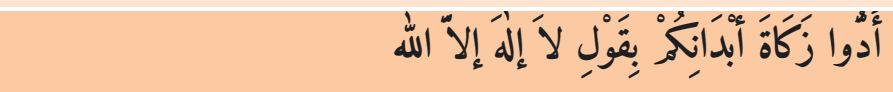 & Ibtidā'I & - & Fāidatul Khabar \\
\hline 14. & ا دَخَلَ الجنَّهَ. & Ibtidā'I & - & Fāidatul Khabar \\
\hline 15. & 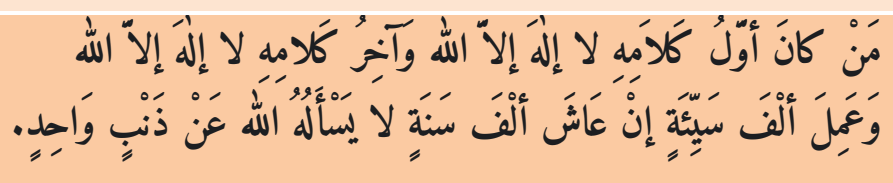 & Ibtidā'I & - & Fāidatul Khabar \\
\hline 16. & 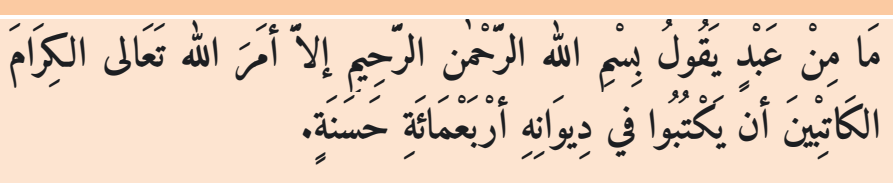 & Ibtidā'I & - & Fāidatul Khabar \\
\hline 17. & 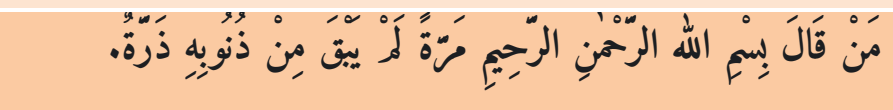 & Ibtidā'I & - & Fāidatul Khabar \\
\hline 18. & 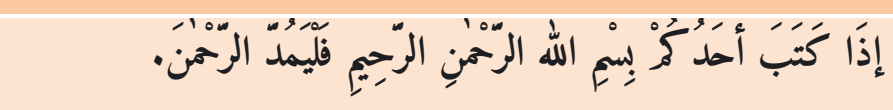 & Ibtidā'I & - & Fāidatul Khabar \\
\hline 19. & 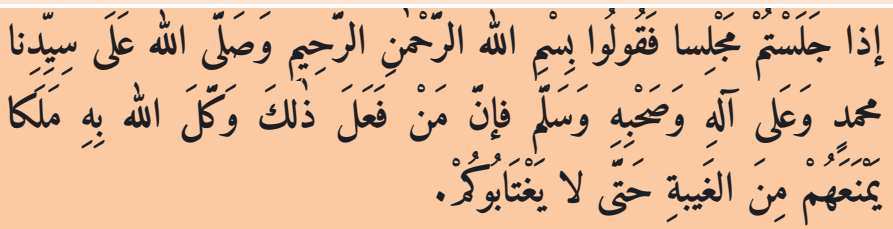 & Ibtidā'I & - & Fāidatul Khabar \\
\hline 20. & مَنْ صَلْى عَلِيّ وَاحِدَةُ صَلَّى الله عَلَيْهِ عَشْرا. & Ibtidā'I & - & Fāidatul Khabar \\
\hline 21. & 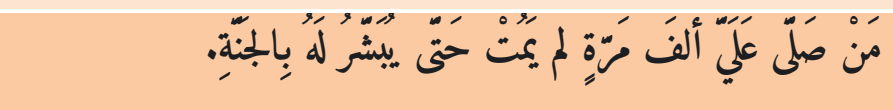 & Ibtidā'I & - & Fāidatul Khabar \\
\hline
\end{tabular}


Kalamuna, Vol. 3. No. 1, Januari 2022. 81 - 104

\begin{tabular}{|c|c|c|c|c|}
\hline 22. & 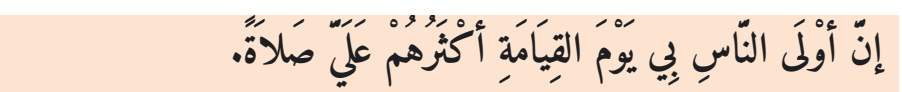 & Țalabi & إنَّ & Fāidatul Khabar \\
\hline 23. & 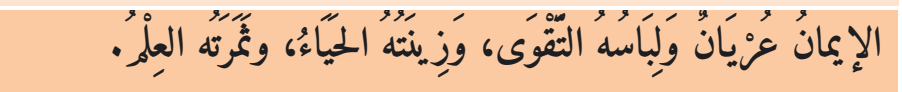 & Ibtidā'I & - & Fāidatul Khabar \\
\hline 24. & لمَنْ لا أَمَانَة لَه. & Ibtidā'I & - & Fāidatul Khabar \\
\hline 25. & لهِ مَا يُحِبُ النَفْسِهِ. & Ibtidā'I & - & Fāidatul Khabar \\
\hline 26. & 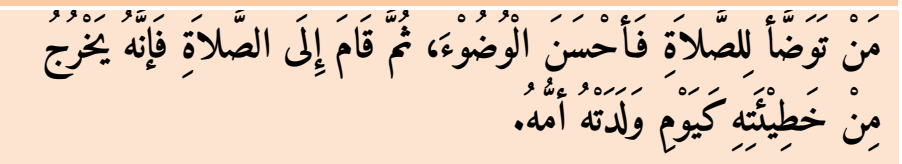 & Ibtidā'I & - & Fāidatul Khabar \\
\hline 27. & 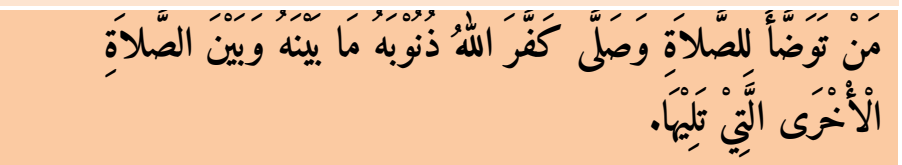 & Ibtidā'I & - & Fāidatul Khabar \\
\hline 28. & 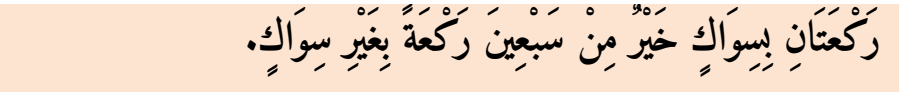 & Ibtidā'I & - & Fāidatul Khabar \\
\hline 29. & 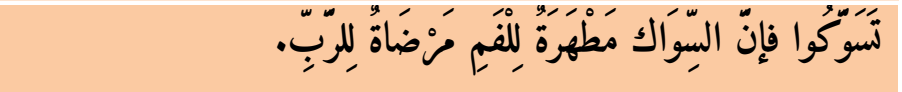 & Talabi & إنَّ & Fāidatul Khabar \\
\hline 30. & 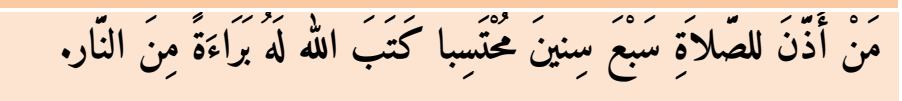 & Ibtidā'I & - & Fāidatul Khabar \\
\hline 31. & 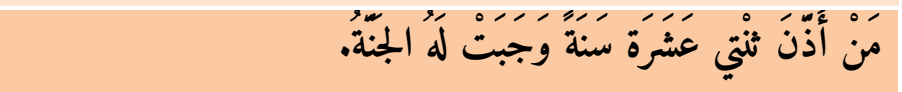 & Ibtidā'I & - & Fāidatul Khabar \\
\hline 32. & 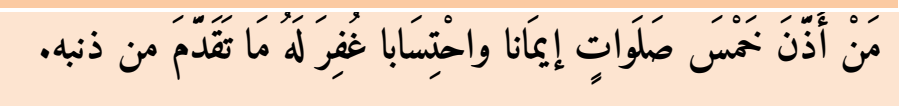 & Ibtidā'I & - & Fāidatul Khabar \\
\hline 33. & 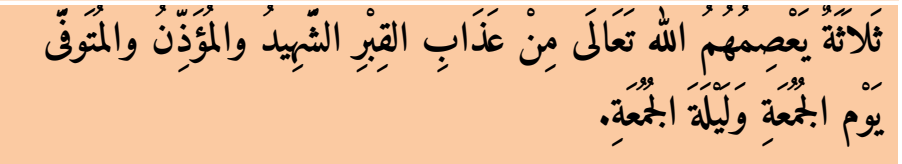 & Ibtidā'I & - & Fāidatul Khabar \\
\hline 34. & 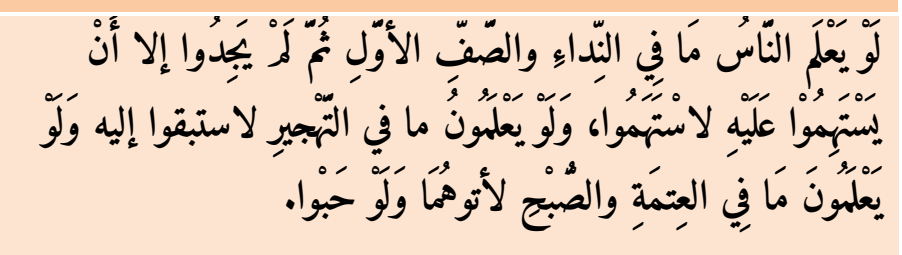 & Ibtidā'I & - & Fāidatul Khabar \\
\hline 35. & 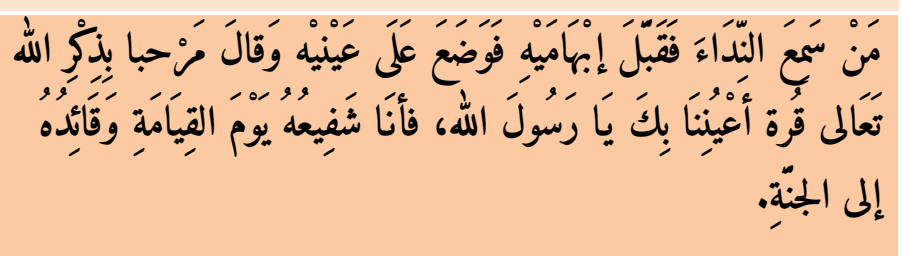 & Ibtidā'I & - & Fāidatul Khabar \\
\hline 36. & 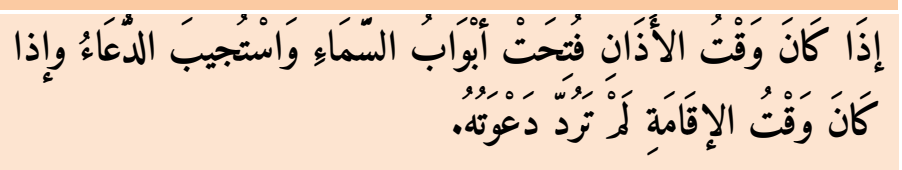 & Ibtidā'I & - & Fāidatul Khabar \\
\hline
\end{tabular}




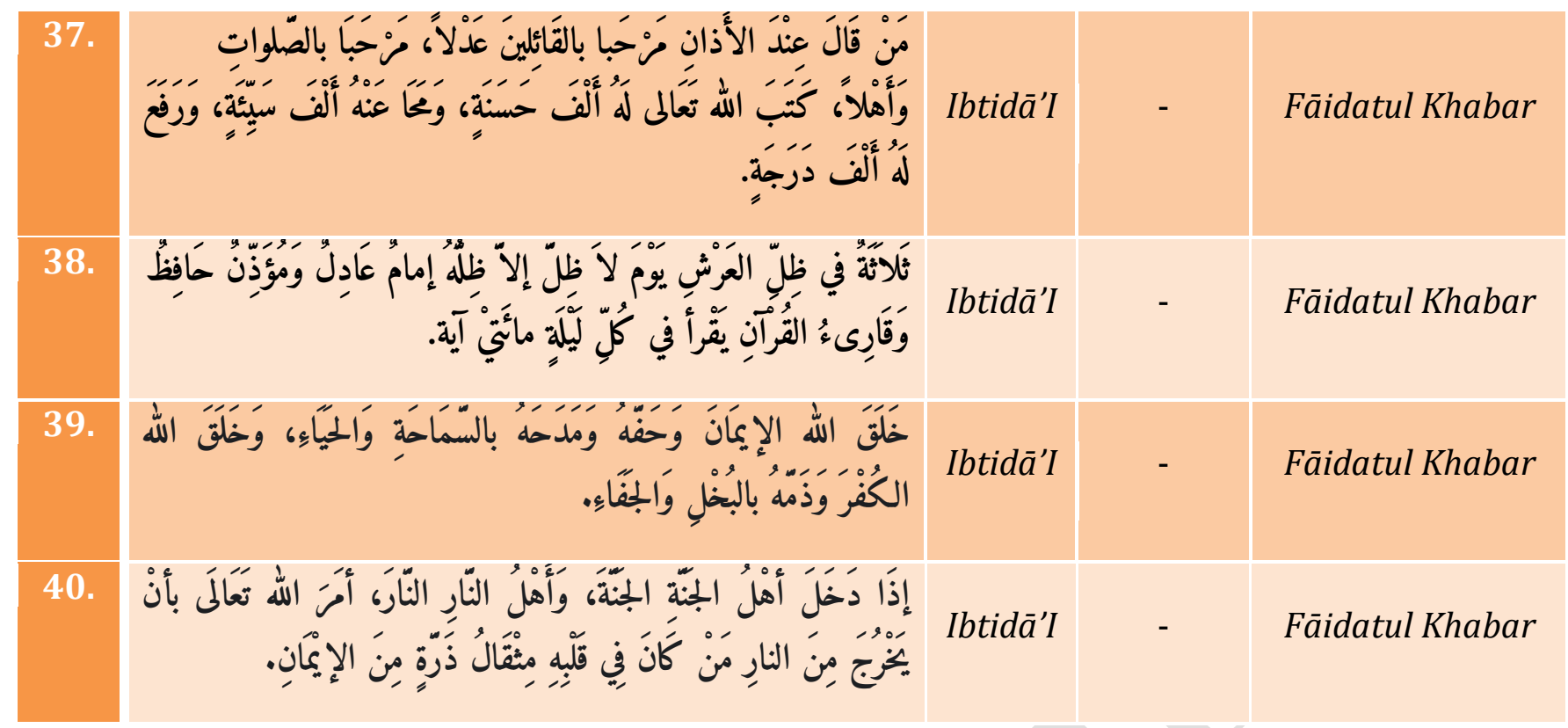

\section{E. Penutup}

Kalām Ibtidā'I terjadi ketika mukhatab dalam kondisi tidak mengetahui sama-sekali khabar yang dikatakan oleh si pembicara atau mukhatab tidak ragu dan tidak mengingkari informasi dari si pembicara, sehingga informasi yang disampaikan oleh si pembicara tanpa harus disertai dengan taukid (penguatan), berbeda dengan Kalām Ibtidā'I, Kalām Khabar Talabi dan Inkāri membutuhkan taukid (penguat) dalam khabar-nya agar mukhatab menerima informasi dari si pembicara. Dalam kasus Hadīs Nab saw., pada kitab Lubāb al-Hadīs, setelah dilakukan analisis ditemukan Kalām Khabar Ibtidā'I sebanyak 88\% dan Kalām Khabar Talabi sebanyak 12\%, sementara tidak ditemukan Kalām Khabar Inkāri.

\section{DAFTAR PUSTAKA}

Abdurrahman al-Ahdhori. 2009. Jauharul Maknun, Terj. Achmad Sunarto. 1st ed. Surabaya: Mutiara Ilmu.

Ahmad Bachdim. 1996. Darsul Balaghah Al-Arabiyah: Al Madkhal Fi Ilmi AlBalaghah WaIlmi Al-Ma'ani. 1st ed. Jakarta: PT Grafindo Persada.

Al-Dzahabi, Muhammad Husain. 1998. Tadzkirah Al-Huffadz. Beirut: Dar El-Kutub Al-Alamiyah.

——_. 2003. "Al-Tafsir Wa Al-Mufassirun." Qohirah: Maktabah Wahbah.

Al-Hanbali, Abû al-Falah'Abd. 1979. "Al-Hayy Ibn Al-'Imâd.” Syadzarat al-Dzahab $f\left\{\left.\right|^{\wedge} \mid i\right\}$ Akhbâri man Dzahab. Dâr al-Fikr.

Al-Jarim, A, and M Amin. 1999. Al-Balaghah Al-Wadhihah: Al-Bayan, Al-Maani, AlBayan Lil Mudaris Al-Thanawiyah. Dar Al-Ma'arif.

Al-Munziri, Imam. 1996. Lc dengan judul Seleksi Hadis-Hadis Shahih Tentang Targhib wat-Tarhib Cet. I Al-Muntawa Min Kitab Al-Targhib Wa Tarhib, Diterjemahkan Oleh Aunur Rafiq Shaleh Tamhid. Jakarta: Rabbani press. 
Amin, Ahmad. 1969. "Fajr Al-Islam (The Dawn of Islam).” Beirut: Dar al-Kitab al'Arabi.[In Arabic].

Azizah, Nuril. 2014. "HADÎTS-HADÎTS TENTANG KEUTAMAAN NIKAH DALAM KITAB LUBÂB AL-HADÎTS KARYA JALÂL AL-DÎN AL-SUYÛTHÎ.” Dialogia: Jurnal Studi Islam dan Sosial 12(1).

Depag RI. 1988. Ensiklopedia Islam Edisi Indonesia. Jakarta.

Diah, Kartiningrum Eka. 2019. "PANDUAN PENYUSUNAN STUDI LITERATUR."

Fajar, Ahmad. 2020. "Tafsir Al- Qur'ān Corak Sastrawi Dan Teologis (Study Kritis Tafsir Al- Kasysyāf Karya Al-Zamakhsyari Pada Ayat-Ayat Mu ḥ Kam Mutasyābih ) Ahmad Fajar 1." Kalamuna 1(1): 36-63.

Jalaluddin al-Suyuthi. 2008. Al-Itqan Fi Ulum Al-Qur'an. Mesir: Darr al-Salam.

Luthfi, Taufik, and Dede Rijal Munir. 2021. "Hubungan Mata Pelajaran Muatan Lokal Bahasa Arab Terhadap Kemampuan Baca Tulis Al-Quran Pada Siswa Kelas IX (Sembilan) SMP Al-Ihsan." Kalamuna: Jurnal Pendidikan Bahasa Arab dan Kebahasaaraban $2(2$ SE-Articles): 172-85. https://ejurnal.staimuttaqien.ac.id/index.php/kalamuna/article/view/289.

Mulyana, Deddy. 2008. "Metodologi Penelitian Kualitatif, Paradigma Baru Ilmu Komunikasi Dan Ilmu Sosial Lainnya." Bandung: Remaja Rosdakarya. 